\title{
Effects of osmotic stress on oxygen consumption and ammonia excretion of the Arctic sympagic amphipod Gammarus wilkitzkii
}

\author{
A. V. Aarset, T. Aunaas \\ Department of Zoology, University of Trondheim, 7055 Dragvoll, Norway
}

\begin{abstract}
Seawater salinity changes affected the metabolic rates of the sympagic (under-ice) amphipod Gammarus wilkitzkii from the Arctic. When amphipods were abruptly transferred from seawater of $35 \%$ to $5 \%$ the rates of both standard specific oxygen consumption $\left(2.31 \pm 0.89 \mu \mathrm{g} \mathrm{g}^{-1}\right.$ dry wt $\left.\mathrm{min}^{-1}\right)$ and ammonia excretion $\left(0.97 \pm 0.17 \mu \mathrm{g}\right.$-at. $\mathrm{NH}_{4}-\mathrm{N} \mathrm{g}^{-1} \mathrm{~d}$. wt $\left.\mathrm{h}^{-1}\right)$ increased about 3 times during the first hours of the exposure and remained high throughout the rest of the experimental period $(72 \mathrm{~h})$. However, metabolic rates appeared to be less sensitive to $24 \mathrm{~h}$ osmotic stress in the salinity range 25 to $48 \%$ compared to exposures of 15 and $5 \%$. The $\mathrm{O}: \mathrm{N}$ atomic ratio of about 21 was constant during hyposmotic stress, indicating protein/lipids as metabolic substrate. Rates of oxygen consumption and ammonia excretion both increased with increasing osmotic difference $(0$ to $450 \mathrm{mOsm}$ ) between the haemolymph and the medium, indicating higher energy requirements for osmotic and ionic regulation at low salinities. A minor decrease in haemolymph sodium concentrations in amphipods exposed abruptly to $5 \%$ coincided with an increased ammonia output during hyposmotic stress, indicating possible counter-ion regulation of $\mathrm{NH}_{4}^{+}$and $\mathrm{Na}^{+}$
\end{abstract}

\section{INTRODUCTION}

Polar sea-ice is a habitat for a diverse group of marine animals. In the Arctic, the true sympagic (under-ice) fauna is dominated by amphipod species such as Apherusa glacialis, Gammarus wilkitzkii and Onisimus glacialis (Gulliksen 1984, Carey 1985, Aarset \& Aunaas 1987 a). If the amphipods are associated with the sea-ice throughout the year, they will be exposed to seasonal changes in physical parameters as the ice melts or freezes (Untersteiner 1968, Cox \& Weeks 1974). Thus, during the summer melt of the ice they are likely to encounter low salinity conditions, and during sea-ice growth may be exposed to high salinity brine at the ice/water interface.

In the Arctic, the sympagic species appear to be euryhaline organisms. The amphipod Gammarus wilkitzkii has been shown to be an osmoregulator at low salinities, displaying regulation of haemolymph concentrations of sodium and chloride (Aarset \& Aunaas 1987a). At high salinities, however, it conforms to the ambient brine with a passive relationship between the haemolymph and seawater inorganic ions (Aarset \& Aunaas 1987b). Although the amphipod has developed physiological mechanisms to cope with variations in seawater salinity, environmental osmotic stress may still interfere with metabolism.

Numerous papers have documented the effect of salinity on the rates of oxygen consumption in crustaceans (Rao 1958, Eltringham 1965, Mclusky 1969, Hagerman 1970, Taylor 1977, Tedengren et al. 1988). Similarly, the effect of salinity on the rates of crustacean ammonia excretion has extensively been studied (Needham 1957, Haberfield et al 1975, Spaargaren et al. 1982, Regnault 1984, Taylor et al. 1987). Several authors have further been focusing on the influence of environmental parameters on the relationship between consumed oxygen and excreted nitrogen (atomic $\mathrm{O}: \mathrm{N}$ ratio), used as an indicator of the kind of metabolic substrate oxidized by the organisms (Mayzaud \& Conover 1988).

In this study, the metabolic response (measured as specific oxygen consumption and ammonia excretion) of the amphipod Gammarus wilkitzkii exposed to various seawater salinities was analyzed. Standard rates of respiration and excretion were estimated according to the activity levels of the amphipods (Clarke 1983). Subsequent estimations of the $\mathrm{O}: \mathrm{N}$ ratio were used to 
clarify the nature of the metabolic substrates oxidized to meet energetic requirements during osmotic stress.

\section{MATERIALS AND METHODS}

Animals. Amphipods Gammarus wilkitzkii were collected in the Barents Sea, east of Svalbard at about $77^{\circ} \mathrm{N}$ and $28^{\circ} \mathrm{E}$ in May 1986 and at $77^{\circ} \mathrm{N} 30^{\circ} \mathrm{E}$ in May 1988. They were sampled from pockets in the multiyear ice-floes by using a diver-operated suction sampler (Aarset \& Willumsen 1985). Salinity (S) of the collected seawater was 34 to $35 \%$, and the temperature was in the range -1.7 to $-0.5^{\circ} \mathrm{C}$. The amphipods were transported to the laboratory of the research vessel in thermos flasks and kept in aerated seawater at $0^{\circ} \mathrm{C}$ and $35 \% \mathrm{~S}$ for $24 \mathrm{~h}$. During this period, they emptied their guts and injured individuals were removed. The amphipods were not fed, and recently moulted individuals and ovigerous females were not used in the experiments. Mean dry weights of the amphipods were about $50 \mathrm{mg}$ in 1986 and $75 \mathrm{mg}$ in 1988.

Experimental protocol. Salinities of 5, 15, 25, 35 and $48 \%$ were used as experimental media. Dilute seawater was prepared by adding distilled water to the acclimation seawater, while concentrated seawater was prepared by adding hypersaline water made by freezing. The samples were aerated in glass vials and stored in darkness in a Thermaks incubator at $0 \pm 0.25^{\circ} \mathrm{C}$.

In 1988 , time-courses ( 0 to $72 \mathrm{~h}$ ) of rates of oxygen consumption and nitrogen excretion were determined simultaneously on amphipods abruptly transferred from 35 to $5 \% \mathrm{~S}$. Time-courses of haemolymph sodium concentrations were determined for amphipods transferred from 35 to $5 \%$. In 1986, the amphipods were transferred from $35 \%$ to each of the 5 experimental media and exposed for $24 \mathrm{~h}$. Rates of oxygen consumption and nitrogen excretion were then determined simultaneously for each specimen, as were haemolymph and exposure media osmolality.

Oxygen consumption. The rate of oxygen consumption of Gammarus wilkitzkii was measured by using a modified version of a constant pressure respirometric method (Engelmann 1963). Each respirometer contained one individual amphipod immersed in $5 \mathrm{ml}$ filtered $(0.2 \mu \mathrm{m})$ seawater In order to keep a constant temperature $\left(0 \pm 0.01^{\circ} \mathrm{C}\right)$, the respirometers were immersed in freshwater/ice in a cooling incubator Respirometers with $5 \mathrm{ml}$ filtered seawater were used as controls. The incubation period in the respirometer was 30 min, after which 4 to 6 measurements (accuracy within $\pm 1 \%$ were made at 10 min intrrvals. The standard respiratory rates were then estimated. The specific rate of oxygen consumption was calculated at standard temperature, pressure and dry conditions (STPD). The dry weight of the amphipods was obtained after drying for $24 \mathrm{~h}$ at $105^{\circ} \mathrm{C}$.

Ammonia excretion. Ammonia was determined as total $\mathrm{NH}_{4}-\mathrm{N}$, or 'ammonia nitrogen', by a modified version of the phenolhypochlorite method of Solorzano (1969). Duplicate seawater samples ( $2 \mathrm{mll}$ ) of the control and test respirometers were transferred to $5 \mathrm{ml}$ volumetric flasks. One-twentieth of the volumes suggested by Solorzano (1969) were used for the chemical analyses. The blue colour of indophenol obtained by the reaction at high $\mathrm{pH}$ of ammonia, phenol and hypochlorite was allowed to develop at room temperature (20 to $24^{\circ} \mathrm{C}$ ) for ca $1 \mathrm{~h}$, and the absorbance was read in a Beckman minispectrophotometer $(1.0 \mathrm{~cm}, 640 \mathrm{~nm})$. Deionized water was used as a blank and $\left(\mathrm{NH}_{4}\right)_{2} \mathrm{SO}_{4}$ as standard. The accuracy of the measurements was within $\pm 1 \%$. The standard ammonia excretion rates of the amphipods were calculated by subtracting the concentration of ammonia in the blank vessel from the concentration in the experimental vessel, multiplied by the total volume of the respiration seawater and divided by the number of hours elapsed.

Osmolality haemolymph - medium. The difference between the osmolality of the haemolymph and that of the exposure medium was determined for 21 amphipods exposed for $24 \mathrm{~h}$ to salinities in the range of 5 to $48 \%$.

Haemolymph sodium concentrations. These were measured following a single-step transfer of 20 amphipods from $35 \%$ seawater to dilute seawater of $5 \%$. Haemolymph was sampled from 3 amphipods at 0 $(35 \%)$ and $1,3,6,12$, and $24 \mathrm{~h}$ after the transfer to $5 \%$.

Sampling. Samples of haemolymph were obtained by inserting a pointed paraffin-filled glass capillary dorsally through the intersegmental membrane. After taking a sample (10 to $50 \mu \mathrm{l}$ ), the capillary was sealed at one end by melting, and centrifuged on a Compur 1100 micro-centrifuge leaving the haemolymph sample isolated under a layer of paraffin oil (Zachariassen et al. 1982) The capillaries were stored frozen $\left(-27^{\circ} \mathrm{C}\right)$.

Analytical methods. Seawater salinity was determined on an Atago refractometer. The osmolality of the seawater and the haemolymph was determined on a Clifton nanolitre osmometer. (Wescor standards) from the melting point of samples with volume 30 to $50 \mathrm{nl}$. The sodium concentration of the haemolymph was determined on a Radiometer. Flame-photometer after diluting 1.5 ul haemolymph with 1000 ul lithium solution in order to operate within the optimised range of the instrument. The accuracy of the measurements was kept within $\pm 1 \%$

Statistics. Due to rather small sample sizes in the experimental groups, the underlying population is assumed to be normally distributed and parametric test 
statistics provided. To reveal possible heterogeneity in the data, a 1-way analysis of variance (ANOVA), using F-statistics, was preferred combined with multiple 2tailed unpaired Student's t-tests. A significance level of $p<0.05$ was chosen. A simple regression model was fitted to the data points by the method of least squares and the correlation coefficient ( $r$ ) used to describe the degree of model fit. The coefficients of the regression line were tested according to the standard error (SE) of the estimate, the t-statistic, and the significance level of these t-values.
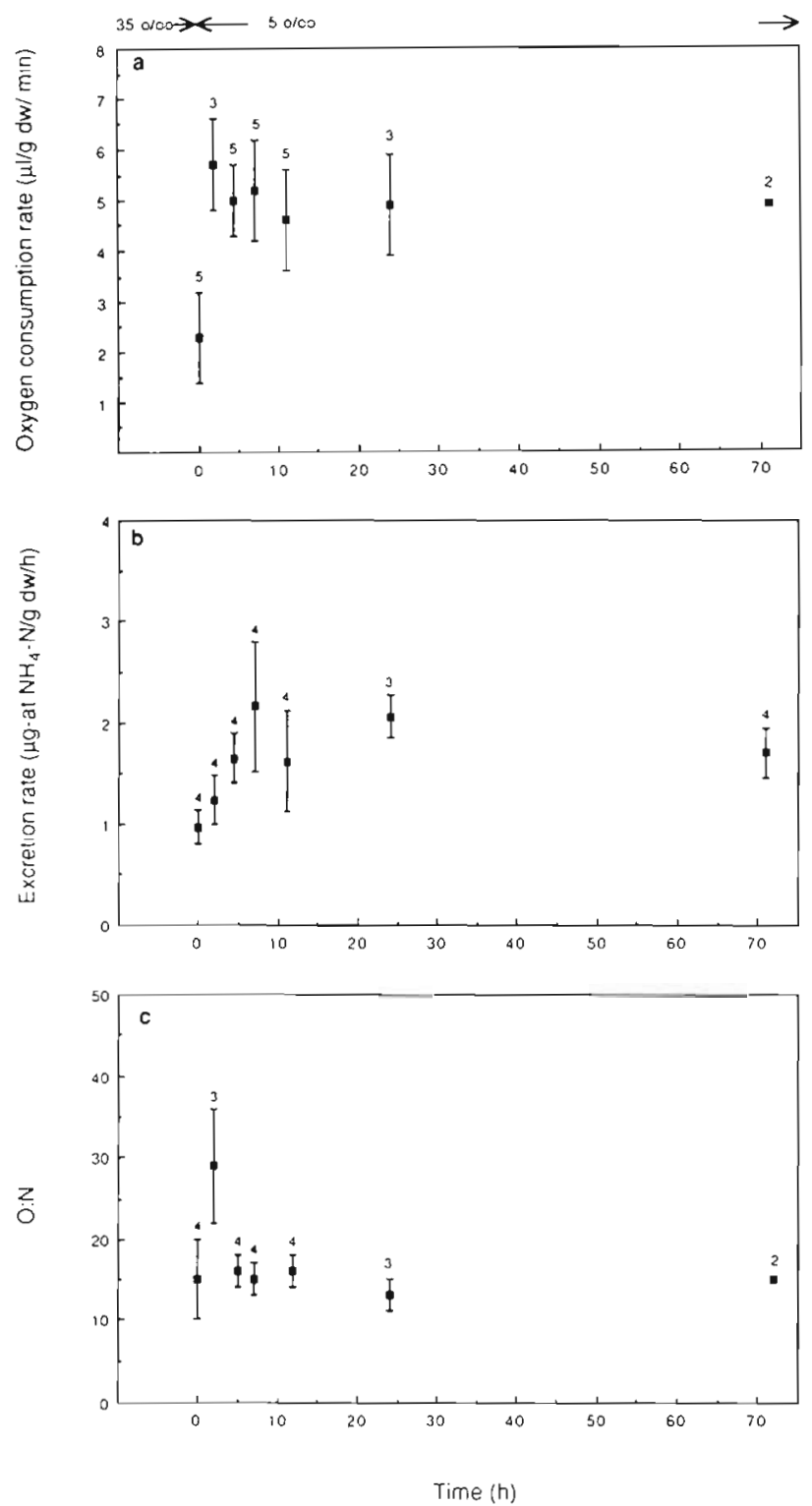

Fig. 1. Gammarus wilkitzkii. Time-courses of (a) rate of specific oxygen consumption, (b) rate of specific ammonia excretion, and (c) O:N ratios with a salinity decrease from 35 to $5 \%$. Data are given as mean $\pm \mathrm{SD}$ with number of individuals indicated above each point

\section{RESULTS}

\section{Time-course of metabolic responses vs low salinity}

Results in Fig. 1a indicate changes in the rates of oxygen consumption with time after transfer from $35 \%$ to $5 \% \mathrm{~S}$ (ANOVA: $F_{(6,21)}=5.47, \mathrm{p}<0.01$ ). The metabolic rate rose significantly after $2 \mathrm{~h}$ (t-test: $\mathrm{df}=6$, $0.01>p>0.001$ ) from an initial value of $2.31 \pm 0.89$, to $5.70 \pm 0.91 \mu \mathrm{g} \mathrm{g}^{-1}$ dry wt min ${ }^{-1}$, representing the peak value of the oxygen consumption rate. This increase
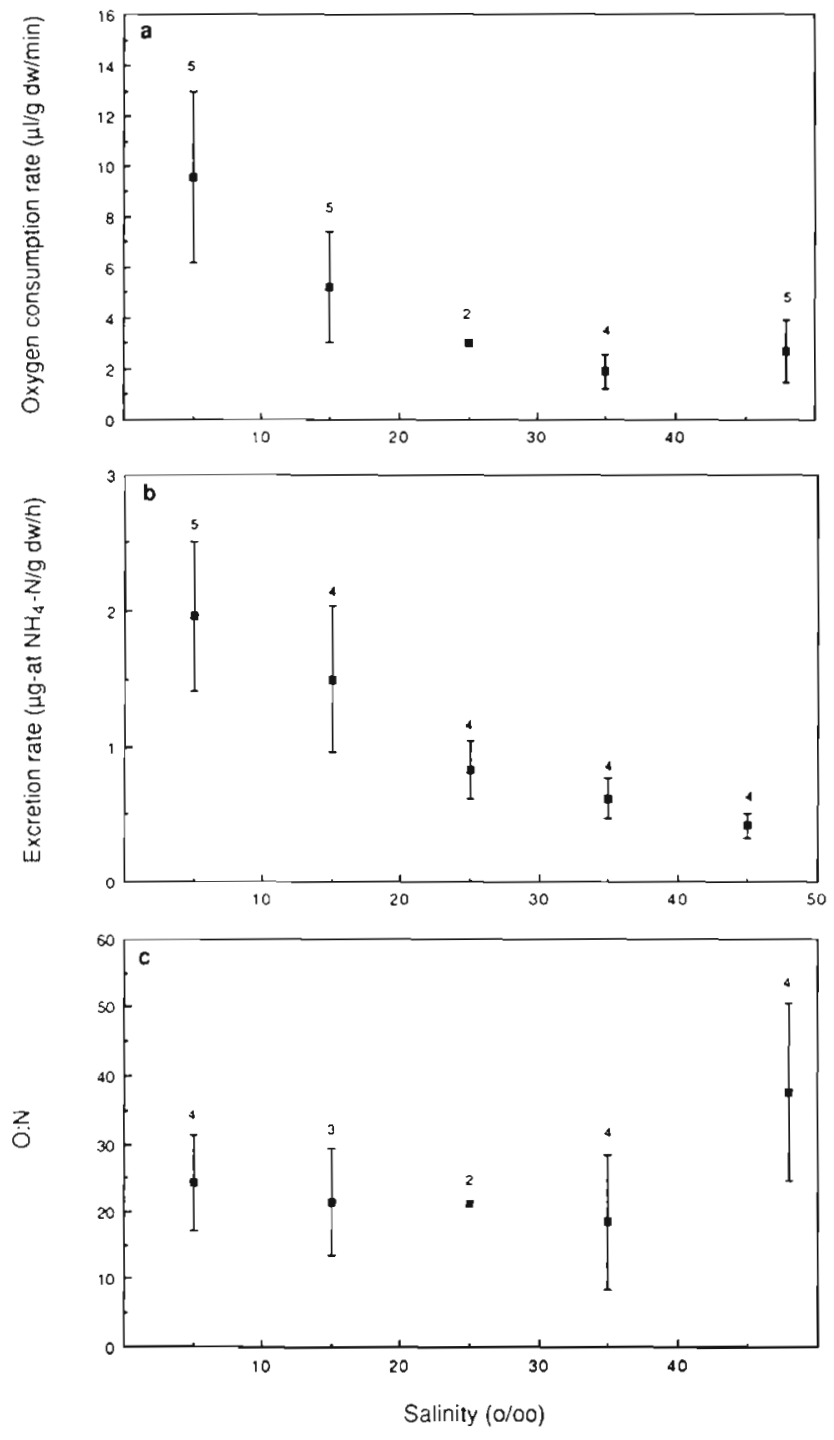

Fig. 2. Gammarus wilkitzkii. (a) Rate of specific oxygen consumption, (b) rate of specific ammonia excretion, and (c) $\mathrm{O}: \mathrm{N}$ ratio for amphipods acclimated for $24 \mathrm{~h}$ to various salinities. Data are given as mean $\pm \mathrm{SD}$ with number of individuals indicated above each point 
was sustained for the rest of the experimental period.

Results in Fig. 1b likewise indicate changes in the rate of ammonia excretion according to time after transfer (ANOVA: $F_{(6.20)}=4.88, p<0.01$ ). Though the excretion rates were at first not significantly different, the rate after $4 \mathrm{~h}$ was significantly greater (t-test: $\mathrm{df}=$ $6,0.01>p>0.001)$ than the initial rate from $0.97 \pm$ 0.17 to $1.65 \pm 0.24 \mu$-at. $\mathrm{NH}_{4}-\mathrm{N} \mathrm{g}^{-1} \mathrm{dry}$ wt $\mathrm{h}^{-1}$. A peak value in ammonia output of $2.16 \pm 0.64 \mu \mathrm{g}$-at. $\mathrm{NH}_{4}-\mathrm{N}$ $\mathrm{g}^{-1}$ dry wt $\mathrm{h}^{-1}$ was reached after $7 \mathrm{~h}$ (t-test: $\mathrm{df}=6,0.05$ $>p>0.01$ ). The excretion rate at the end of the experi-
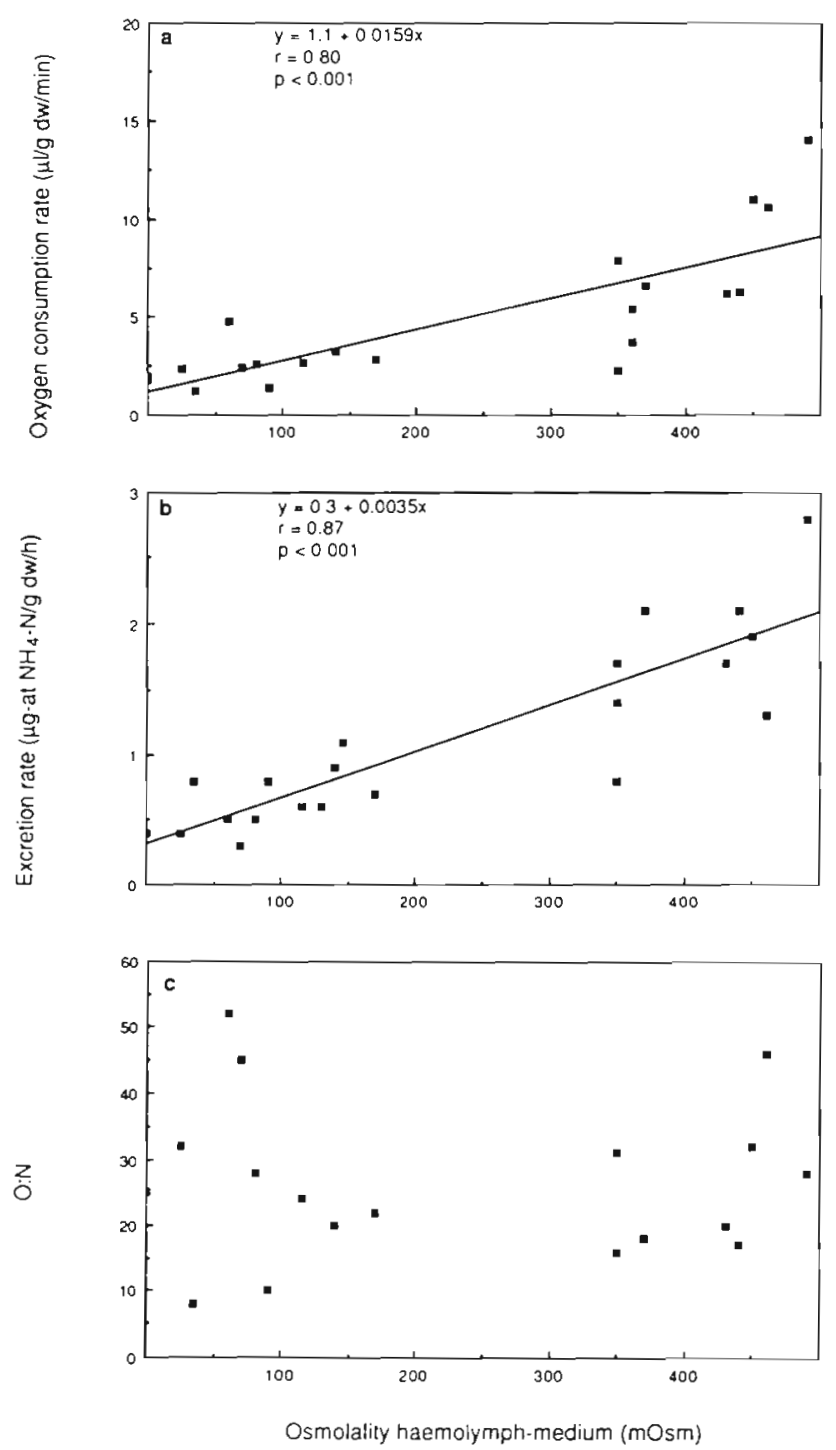

Fig. 3. Gammarus wilkitzkii. (a) Rate of specific oxygen consumption, (b) rate of specific ammonia excretion, and (c) $\mathrm{O}: \mathrm{N}$ ratio as a function of osmotic difference between haemolymph and medium osmolality. The simple regressions are indicated by solid lines mental period $(72 \mathrm{~h})$ was $1.65 \pm 0.26 \mu \mathrm{g}$-at. $\mathrm{NH}_{4}-\mathrm{N} \mathrm{g}^{-1}$ dry $w t h^{-1}$, significantly greater (t-test: $\mathrm{df}=6,0.01>\mathrm{p}$ $>0.001)$ than the initial rate.

Results in Fig. 1C indicate changes in the $O: N$ ratios of the amphipods with time after transfer (ANOVA: $\left.F_{(6,1.7)}=5.98, p<0.01\right)$. The $\mathrm{O}: \mathrm{N}$ ratio rose significantly after $2 \mathrm{~h}$ (t-test: $\mathrm{df}=5,0.05<\mathrm{p}<0.01$ ) from an initial value of $16.0 \pm 5.5$ to $29.0 \pm 7.0$, representing the peak value of the ratio. After $5 \mathrm{~h}$ the ratio had declined to $16.0 \pm 1.5$ and was constant for the rest of the experimental period $(72 \mathrm{~h})$.

\section{Metabolic responses vs salinity acclimation}

Fig. 2a shows changes in the rates of specific oxygen consumption vs salinity (5 to $48 \%$ ) (ANOVA: $F_{(4,16)}=$ 9.83, $p<0.01)$. The lowest mean rate of $1.89 \pm 0.71 \mu \mathrm{l}$ $\mathrm{g}^{-1}$ dry wt min $^{-1}$ was obtained at salinity $35 \%$. When the amphipods were exposed to a hyposmotic stress a significant rise in the oxygen consumption rates occurred at salinity $15 \%$, to $5.14 \pm 2.24 \mu \mathrm{g} \mathrm{g}^{-1}$ dry wt min ${ }^{-1}$ (t-test: $\mathrm{df}=7,0.05>\mathrm{p}>0.01$ ) and at $5 \%$ to $9.62 \pm 3.38$ $\mu \mathrm{g}^{-1}$ dry wt $\min ^{-1}$ (t-test: $\mathrm{df}=7,0.01>\mathrm{p}>0.001$ ) However, there was no significant difference between the specific oxygen consumption rates of amphipods at normal salinity $(35 \%)$ and those under hyperosmotic stress $(48 \%)$ ( $t$-test: $d f=7, p>0.1)$.

Fig. $2 b$ shows changes in the rates of ammonia excretion vs salinity (ANOVA: $F_{(4,16)}=12.03, p<0.01$ ). A mean rate of $0.65 \pm 0.19 \mu \mathrm{g}$-at. $\mathrm{NH}_{4}-\mathrm{Ng}^{-1}$ dry wt $\mathrm{h}^{-1}$ was obtained for amphipods at salinity $35 \%$. Exposure to hyposmotic stress induced a significant increase in nitrogen excretion rates at salinity $15 \%$, to $1.50 \pm$ $0.54 \mu$-at. $\mathrm{NH}_{4}-\mathrm{N} \mathrm{g}^{-1}$ dry wt h ${ }^{-1}$ (t-test: $\mathrm{df}=6,0.05>$ $\mathrm{p}>0.01$ ) and at $5 \%$ to $1.96 \pm 0.55 \mu \mathrm{g}$-at. $\mathrm{NH}_{4}-\mathrm{Ng}^{-1}$ dry wt $\mathrm{h}^{-1}$ (t-test: $\left.\mathrm{df}=7,0.01>\mathrm{p}>0.001\right)$. The lowest rate of $0.42 \pm 0.1 \mu \mathrm{g}$-at. $\mathrm{NH}_{4}-\mathrm{N} \mathrm{g}^{-1}$ dry wt $\mathrm{h}^{-1}$ was obtained for amphipods exposed to hyperosmotic stress $(48 \%)$. However, this rate was not significantly different from the rate at $35 \%(\mathrm{df}=6, \mathrm{p}>0.05)$

No significant changes occurred in $O: N$ atomic ratios vs salinity (Fig 2c) (ANOVA: $F_{(4,12,}=2.13, p>0.05$ )

\section{Metabolic responses vs osmolality differences}

Rates of specific oxygen consumption increased with an increasing osmotic difference between the medium and the haemolymph (Fig. 3a). A simple regression model was fitted to the points. The slope $(0.0159 \pm$ 0.003 [SE]) of the regression line was significantly different from a line of slope zero $(t=5.84, p<0.001)$. The intercept of the line, $1.1283 \pm 0.788$ (SE), was not significantly different from zero $(\mathrm{t}=1.43, \mathrm{p}>0.1)$. At 
an osmotic difference of zero, the specific oxygen consumption rate was $1.13 \mu \mathrm{l} \mathrm{g}^{-1}$ dry wt $\mathrm{min}^{-1}$. However, an osmotic difference of 450 mOsm gave a specific oxygen consumption rate of $8.28 \mu \mathrm{g} \mathrm{g}^{-1}$ dry wt min ${ }^{-1}$, a 7 -fold increase. The correlation coefficient ( $r$ ) demonstrated a close fit to the regression model (Fisher: $\mathrm{df}=$ 19, $\mathrm{p}<0.001$ ).

Rates of ammonia excretion increased with increasing osmotic difference between the haemolymph and the medium (Fig. 3b). A simple regression model was fitted to the points. The slope $(0.0035 \pm 0.0001$ [SE]) of the regression line was significantly different from zero $(t$-test: $\mathrm{t}=7.79, \mathrm{p}<0.001)$. The intercept $(0.3124 \pm$ 0.128 [SE]) of the line was also significantly different from zero $(t=2.44,0.05>p>0.01)$. At an osmotic difference of zero, the excretion rate was $0.31 \mu \mathrm{g}$-at. $\mathrm{NH}_{4}-\mathrm{N} \mathrm{g}^{-1}$ dry wt $\mathrm{h}^{-1}$. An osmotic difference of $450 \mathrm{mOsm}$, however, gave an excretion rate of $1.88 \mu \mathrm{g}-$ at. $\mathrm{NH}_{4}-\mathrm{N} \mathrm{g}^{-1}$ dry wt $\mathrm{h}^{-1}$ which represents an increase of about 6 times the rate at zero osmotic difference. The correlation coefficient (r) demonstrated a close fit to the regression model (Fisher: $\mathrm{df}=19, \mathrm{p}<0.001$ ).

No significant relationship was found between $O: N$ atomic ratio and the osmotic difference between the haemolymph and the environmental medium (Fig. 3c).

\section{Haemolymph sodium concentrations}

Fig. 4 shows changes in the sodium concentration in the haemolymph of the amphipods vs time after transfer from $35 \%$ to $5 \% \mathrm{~S}$ (ANOVA: $F_{(5.12)}=16.14, \mathrm{p}$ $<0.01)$. The sodium concentration decreased significantly (t-test: $\mathrm{df}=4,0.01>\mathrm{p}>0.001$ ) after $1 \mathrm{~h}$ from an initial value of $475 \pm 13$ to $370 \pm 30 \mathrm{mmol} \mathrm{l}^{-1}$. A further

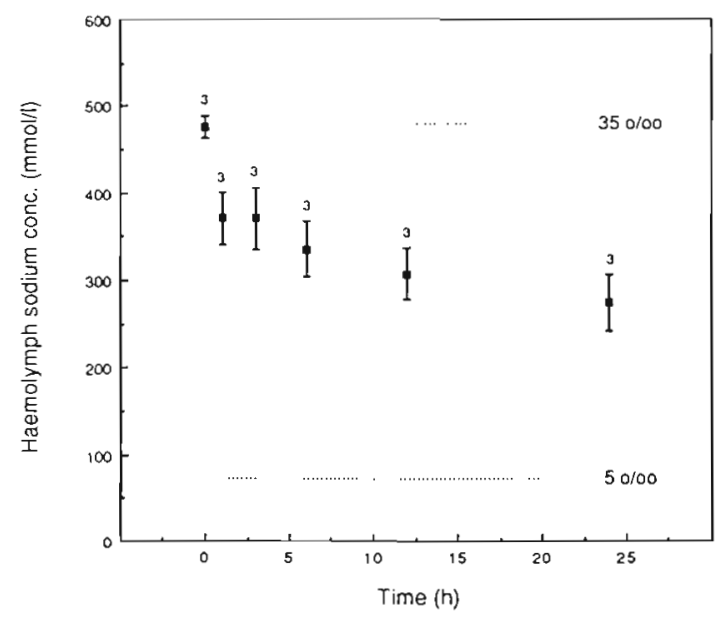

Fig. 4. Gammarus wilkitzkii. Time-course of haemolymph sodium concentrations with a salinity decrease from 35 to $5 \%$. Data are given as mean $\pm S D$ with number of individuals indicated above each point reduction in concentrations occurred at $6 \mathrm{~h}$ and at $12 \mathrm{~h}$. However, these concentrations were not significantly different from the concentration of $273 \pm 32 \mathrm{mmoll}^{-1}$ at $24 \mathrm{~h}$, indicating that the sodium concentrations in the haemolymph stabilize after ca $6 \mathrm{~h}$.

\section{DISCUSSION}

The present study indicates that changes in seawater salinity affect the metabolic rates of the sympagic amphipod Gammarus wilkitzkii. This may be of ecological significance for the amphipods in the Arctic seaice.

The observed increase in the rate of oxygen consumption at low salinities has previously been recorded for several other crustacean species. To provide information on the time-course and capacity of adaptation to salinity in amphipods, Bulnheim (1972) studied oxygen consumption rates following osmotic stress in 5 euryhaline species. He concluded that the estuarine amphipod Gammarus duebeni exhibited higher capabilities of compensatory adjustment than the marine amphipod Gammarus locusta, and that a new steady state metabolic rate following stress was reached faster $(3 \mathrm{~h})$ in the estuarine than in the marine species $(30 \mathrm{~h})$. The time-course of the specific oxygen consumption rate of $G$. wilkitzkii transferred from $35 \%$ to $5 \%$ seawater (Fig. 1a) indicated that this amphipod elevated the rate just after transfer and kept it high throughout the experimental period $(72 \mathrm{~h})$. This result may indicate that the salinity-induced metabolic response of the Arctic amphipod is slower than demonstrated by the estuarine organism which has to cope daily with rapid salinity fluctuations.

An increased ammonia excretion rate in dilute media has been noted in a number of crustacean species such as the shrimp Crangon crangon (Regnault 1984), the prawn Palemon elegans (Taylor et al. 1987), the shore crab Carcinus maenas (Needham 1957. Haberfield et al. 1975, Spaargaren et al. 1982, Harris \& Andrews 1985) and the blue crab Callinectes sapidus (Mangum et al. 1976). However, the time-course of the rate of ammonia excretion during hyposmotic stress has proved to vary considerably between the crustacean species studied. The euryhaline crab C. sapidus demonstrated only a transient change in ammonia output during hyposaline exposure, which decreased within $24 \mathrm{~h}$ to levels not significantly different from control crabs in full-strength seawater (Mangum et al. 1976). The response of $P$. elegans was a large, but transient change that stabilized within a few hours at a rate slightly higher than that of controls (Taylor et al. 1987). In Gammarus wilkitzkii, a peak value of excretion rate was reached after $7 \mathrm{~h}$ and remained fairly 
constant for about $72 \mathrm{~h}$ (Fig. 1b). This observation supports the idea that the sympagic amphipod responds slowly in the process of adaptation.

A metabolic substrate of only proteins should give a minimum $O: N$ ratio of 7 (Mayzaud 1973) with equivalent weights of proteins and lipids a ratio of 24 is obtained, and if lipids and carbohydrates are metabolized, the ratio would approach infinity (Conover \& Corner 1968).

Stern et al. (1984) have demonstrated a change in energy substrate utilization as a function of osmotic stress in the freshwater prawn Macrobrachium rosenbergii. Tendengren et al. (1988) observed further lowered $\mathrm{O}: \mathrm{N}$ ratios for amphipods in altered salinities. However, changes in the time-course of $\mathrm{O}: \mathrm{N}$ ratios in Gammarus wilkitzkii occurred during the first hours of hyposmotic stress (Fig. 1C). In amphipods exposed to $35 \%$ salinity, a ratio of about 16 reflected lipid/protein catabolism. A temporary increase in the ratio to about 30 seemed to be a result of differences in the immediate rate-response of oxygen and nitrogen.

The steady-state oxygen consumption rate of Gammarus wilkitzkii was salinity-independent in the range between 25 and $48 \%$, thereby compensating for the changes in seawater salinity (Fig. 2a). Below a salinity of 15 to $20 \%$, G. wilkitzkii was rather sensitive to salinity stress, with a 2 to 3 times increase in the specific oxygen consumption rate when transferred from 35 to $15 \%$. This indicates that the amphipods can live close to the sea-ice environment in the compensated salinity range with minor changes in energy requirements. In an environment with wider changes in salinities (below 15 to $20 \%$ ), the amphipod will need higher energy input. It is questionable whether the amphipods are able to maintain such high metabolic rates for long periods, in fact a migration to seawater of higher salinity might be favourable. However, a long acclimation period of $G$. wilkitzkii to low salinity might induce morphological changes in the amphipod gills (Gilles \& Pequeux 1985). According to Milne \& Ellis (1973), exposure of the marine amphipod Cammarus oceanicus to $20 \%$ artificial seawater resulted in invagination of the apical cell membranes and an increase in numbers of mitochondria, reflecting the increased rate of oxygen consumption by the gill cells.

Exposure of Gammarus wilkitzkii to 24 h hyposmotic stress resulted in a substantial increase in ammonia excretion rates of indjviduals exposed to salinities below $25 \%$ (Fig. 2 b). Thus, the excretion rate to some extent seems to follow the changes in oxygen consumption rate. In the salinity-independent range of 25 to $48 \%$ there was a small but significant decrease in excretion rate with increasing salinity $(0.05<p<0.01)$ The amphipods, therefore, were not fully compensating for the salinity variations in the media. Exposure to salinities below 15 to $20 \%$ revealed sensitivity to the salinity stress with a 2 to 3 times increase in the excretion rate. This observation and the concomitant elevation of the oxygen consumption rates suggest that under such conditions it would be energetically favourable for the amphipods to migrate into waters of higher salinities.

In Gammarus wilkitzkii the pooled O: $\mathrm{N}$ ratio for $24 \mathrm{~h}$ osmotic stress varied from 21 under hyposmotic to 37 under hyperosmotic stress (Fig. 2c). However, because of large individual variations in the ratios, the differences were not significant. Ikeda \& Bruce (1986) pooled data for 12 Antarctic zooplankton species resulting in an $O: N$ ratio of about 14 . Antarctic krill Euphausia crystallorophia had a ratio of 26 (Biggs 1982), while starved krill Euphausia superba displayed ratios ranging from 21 to 50 (Hirche 1983).

In many crustaceans the respiratory rate has been demonstrated to be highest when the osmotic difference between haemolymph and external medium is at a maximum (Rao 1958, King 1965, Hagermann 1970). The lowest respiratory rate occurred when the osmotic difference between haemolymph and medium was minimal. This often occurred at the in situ salinity experienced by the animals (Dimock \& Groves 1975) These observations were supported in the present study of Gammarus wilkitzkii (Fig. 3a). As the amphipod was an osmoregulator at salinities lower than $25 \%$, maintaining an elevated haemolymph concentration of $\mathrm{Na}^{+}$and $\mathrm{Cl}^{-}$(Aarset \& Aunaas 1987a), the observed rise in the oxygen consumption rates thus seem to indicate an increased energy requirement for osmotic regulation at low salinities. Florey (1966) has suggested that about $75 \%$ of the total energy derived from oxidative metabolism of resting frog muscle has to be used for $\mathrm{Na}^{+}$extrusion.

However, the energy actually required for osmo- and ionic-regulation in crustacean species, calculated from thermodynamic considerations, has been claimed to account for only a minor part ( 1 to $5 \%$ ) of the observed increase in the oxygen consumption rate (Potts 1954, Styczynska-Jurewicz 1970, Spaargaren 1975, Dalla Via 19871. Another reason for the accelerated respiratory rates may be related to the catabolism of free amino acids during cell volume requlation, as the control of the amino acid pool is governed mostly by changes in transport activity, deamination and oxidation of the acids to $\mathrm{CO}_{2}$ (Gilles 1973).

Mangum et al. (1976) demonstrated for the crab Callinectes sapidus that ammonia excretion was related to the osmotic difference between blood and water These observations were supported by the present results for excretion rate of Gammarus wilkitzkii in the osmotic difference range from 0 to $450 \mathrm{mOsm}$. At the latter level the amphipods suffer an increasing $\mathrm{N}$ 
loss to the environment (Fig. 3b). The main site of ammonia transfer in crustaceans appears to be the gill epithelium, which can be traversed via various pathways (Evans \& Cameron 1986). The $\mathrm{NH}_{4}^{+}$ion has been proposed to act as a counter-ion in the regulation of haemolymph sodium concentrations (Weiland \& Mangum 1975, Kirschner 1979, Taylor et al. 1987). Thus, a minor decrease in haemolymph sodium would coincide with increased ammonium output during hyposmotic stress. In $G$. wilkitzkii the time-course of the haemolymph sodium concentration tends to support this hypothesis (Fig. 4). However, Evans \& Cameron (1986) doubted the existence of a $\mathrm{Na}^{+} / \mathrm{NH}_{4}$ exchange mechanism in crustaceans.

In several crustacean species, the rate of ammonia excretion may be reduced during long-term exposure to hyperosmotic stress (Needham 1957, Mangum et al. 1976). In Gammarus wilkitzkii there was a significant decrease in excretion rate of individuals exposed to salinities from 25 to $48 \%$, indicating a metabolic importance of the $\mathrm{NH}_{4}^{+}$ion at higher salinities (Fig. 2b). Armstrong et al. (1981) first documented an ammonia uptake from a hyperosmotic medium in the freshwater prawn Macrobrachium rosenbergii, and suggested a reversal of the $\mathrm{Na}^{+} / \mathrm{NH}_{4}^{+}$exchange mechanism, allowing the prawns to hyporegulate in concentrated media. However, in $G$. wilkitzkii no ability to hyporegulate has been demonstrated so far (Aarset \& Aunaas 1987b). Hyporegulation would raise the melting point of the amphipod haemolymph above that of the surrounding seawater, and under such circumstances ice nucleation would be likely to occur at low temperature exposure underneath the Arctic sea-ice.

Acknowledgements. This work is part of the PRO MARE program and has been financed by the Norwegian Research Council for Science and Humanities and the oil company FINA (BECTOS). The authors thank crew and colleagues on board the Coast Guard vessels for assistance during the expeditions, A. Lohrman for technical assistance, Prof. K. E. Zachariassen for reading the manuscript and $\mathrm{L}$. Gilstad for improving the language.

\section{LITERATURE CITED}

Aarset, A. V., Aunaas, T. (1987a). Osmotic responses to hyposmotic stress in the amphipods Gammarus wilkitzkii, Onisimus glacialis and Parathemisto libellula from Arctic waters. Polar Biol. 7: 189-193

Aarset, A. V., Aunaas, T (1987b). Physiological adaptation to low temperature and brine exposure in the circumpolar amphipod Gammarus wilkitzküi. Polar Biol. 8: 129-133

Aarset, A. V., Willumsen, F. (1985). Hydraulic based sampling equipment for under-ice fauna. Polar Res. 3: 253-255

Armstrong, D. A., Strange, K., Crowe, J., Knight, A., Simmons, M. (1981). High salinity acclimation by the prawn Macrobrachium rosenbergii: uptake of exogenous ammonia and changes in endogenous nitrogen compounds. Biol. Bull. mar. biol. Lab., Woods Hole 160: 349-365
Biggs, D. C. (1982). Zooplankton excretion and $\mathrm{NH}_{4}$ cycling in the near-surface waters of the Southern ocean. I. Ross Sea, austral summer 1977-1978. Polar Biol. 1. 55-67

Bulnheim, H. P. (1972). Vergleichende Untersuchungen zur Atmungsphysiologie euryhaliner Gammariden unter besonderer Berücksichtigung der Salzgehaltsanpassung. Helgoländer wiss. Meeresunters. 23: 485-534

Carey, A. G. Jr (1985). Marine ice fauna: Arctic. In: Horner, R. A. (ed.) Sea ice biota. CRC Press, Florida, p. 173-190

Clarke, A. (1983). Life in cold water: the physiological ecology of polar marine ectotherms. Oceanogr mar Biol. A. Rev. 21: $341-453$

Conover, R. J., Corner, E. D. S. (1968). Respiration and nitrogen excretion by some marine zooplankton in relation to their life cycles. J. mar biol. Ass. U.K. 48: 49-75

Cox, G. F. N., Weeks, W. F. (1974). Salinity variations in sea ice. J. Glaciol 13: 109-120

Dalla Via, G. J. (1987). Effects of salinity and temperature on oxygen consumption in a freshwater population of Palaemonetes antennarius (Crustacea, Decapoda). Comp. Biochem. Physiol. 88: 299-305

Dimock, R. V. Jr, Groves, K. H. (1975). Interaction of temperature and salinity on oxygen consumption of the estuarine crab Panopeus herbstii. Mar Biol. 33: 301-308

Eltringham, S. K. (1965). The respiration of Limnoria (Isopoda) in relation to salinity. J. mar biol. Ass. U.K. 45: 145-152

Engelmann, M. D. (1963). A constant pressure respirometer for small arthropods. Ent. News 74: 181-187

Evans, D. H., Cameron, J. N. (1986). Gill ammonia transport. J. exp. Zool. 239: 17-23

Florey, E. (1966). Bioelectricity. In: Florey, E. (ed.) General and comparative animal physiology. W. B. Saunders, London, p. 375-417

Gilles, R. (1973). Oxygen consumption as related to the aminoacid metabolism during osmoregulation in the blue crab Callinectes sapidus. Neth. J. Sea Res. 7: 200-207

Gilles, R., Pequeux, A. (1985). Ion transport in crustacean gilles: physiological and ultrastructural approaches. In: Gilles, R., Gilles-Baillien, M. (eds.) Transport processes, iono- and osmoregulation. Current comparative approaches. Springer, Berlin, p. 136-158

Gulliksen, B. (1984). Under-ice fauna from Svalbard waters. Sarsia 69: 17-23

Haberfield, E. C., Haas, L. W., Hammen, C. S. (1975). Early ammonia release by a polychaete Nereis virens and a crab Carcinus maenas in diluted sea water. Comp. Biochem. Physiol. 52: 501-503

Hagerman, L. (1970). The oxygen consumption of Crangon vulgaris (Fabricius) (Crustacea, Natantia) in relation to salinity. Ophelia 7: 283-292

Harris, R. R., Andrews, M. B. (1985). Total NPS pool and ammonia net efflux rate changes in Carcinus maenas during acclimation to low environmental salinity. Comp. Biochem. Physiol. 82A: 301-308

Hirche, H. J. (1983). Excretion and respiration of the Antarctic krill Euphausia superba. Polar Biol. 1: 205-209

Ikeda, T., Bruce, B. (1986). Metabolic activity and elemental composition of krill and other zooplankton from Prydz Bay, Antarctica, during early summer (November-December). Mar. Biol. 92: 545-555

King, E. N. (1965). The oxygen consumption of intact crabs and excised gills as a function of decreased salinity. Comp. Biochem. Physiol. 15: 93-102

Kirschner, L. B. (1979). Control of the extracellular fluid osmolarity, control mechanisms in crustaceans and fishes. In: Gilles, R. (ed.) Mechanisms of osmoregulation in animals. Wiley, New York, p. 157-222 
Mangum, C. P., Silverthorn, S. U., Harris, J. L., Towle, D. W., Krall, A. R. (1976). The relationship between blood $\mathrm{pH}_{1}$ ammonia excretion and adaptation to low salinity in the blue crab Callinectes sapidus. J. exp. Zool. 195: 129-136

Mayzaud, P. (1973). Respiration and nitrogen excretion of zooplankton. II Studies of metabolic characteristics of starved animals. Mar Biol. 21. 19-28

Mayzaud, P., Conover, R. J. (1988). O:N atomic ratio as a tool to describe zooplankton metabolism. Mar. Ecol. Prog. Ser. 45: 289-302

McLusky, D. (1969). The oxygen consumption of Corophium volutator in relation to salinity. Comp. Biochem. Physiol 29: 743-753

Milne, D. J., Elhs, R. A. (1973). The effect of salinity acclimation on the ultrastructure of the gills of Gammarus oceanicus (Segerstale, 1947) (Crustacea, Amphipoda). Z. Zellforsch. 139: 311-318

Needham, A. E. (1957). Factors effecting nitrogen excretion in Carcinus maenas (Pennant). Physiologia comp. Oecol. 4 : 209-239

Potts, W T. W. (1954). The energetics of osmotic regulation in brackish- and fresh-water animals. J. exp. Biol. 31: $618-630$

Rao, K. P. (1958). Oxygen consumption as a function of size and salinity in Metapenaeus monoceros Fab. from marine and brackish-water environments. $J$ exp. Biol. 35 $307-313$

Regnault, M. (1984). Salinity-induced changes in ammonia excretion rate of the shrimp Crangon crangon over a winter tidal cycle. Mar. Ecol. Prog. Ser. 20: 119-125

Solorzano, L. (1969). Determination of ammonia in natural waters by the phenolhypochlorite method. Limnol. Oceanogr. 14: 799-801

This article was submitted to the editor
Spaargaren, D. H. (1975). Energy relations in the ion regulation in three crustacean species. Comp. Blochem. Physiol. 51. $543-548$

Spaargaren, D. H., Richard, P., Ceccaldi, H. I. (1982). Excretion of nitrogenous products by Penaeus japonicus Bate in relation to environmental osmotic conditions. Comp. Biochem. Physiol. 720: 673-678

Stern, S. Borut, A., Cohen, D. (1984). The effect of salinity and ion composition on oxygen consumption and nitrogen excretion of Macrobrachium rosenbergii. Comp. Biochem. Physiol. 79: 271-274

Styczynska-Jurewicz, E. (1970). Bioenergetics of osmoregulation in aquatic animals. Pol. Arch. Hydrobiol. 17: 295-302

Taylor, A. C. (1977). The respiratory responses of Carcinus maenas (L.) to changes in environmental salinity. J. exp. mar. Biol. Ecol. 29: 197-210

Taylor, A. C., Spicer, J. I., Preston, T (1987). The relationship between osmoregulation and nitrogen metabolism in the intertidal prawn. Palaemon elegans (Rathke). Comp. Biochem. Physiol. 88: 291-298

Tedengren, M., Arner, M., Kautsky, N. (1988). Ecophysiology and stress response of marine and brackish water Gammarus species (Crustacea. Amphipoda) to changes in salinity and exposure to cadmium and diesel-oil. Mar. Ecol. Prog. Ser. 47: 107-116

Untersteiner, N. (1968). Natural desalination and equilibrium salinity profile of old sea ice. J. geophys. Res. 73: 519-543

Weiland, A. L., Mangum, C. P. (1975). The influence of environmental salinity on hemocyanin function in the blue crab. Callinectes sapidus. J. exp. Zool. 193: 265-274

Zachariassen, K. E., Baust, J. G., Lee, R. E. (1982). A method for quantitative determination of ice nucleating agents in insect haemolymph. Cryobiology 19: 180-184

Manuscript first received: January 31, 1989

Revised version accepted: August 28, 1989 